\title{
THE INFLUENCE OF DISCIPLINE, LEARNING FACILITIES, AND FRIENDS CLASS TO ECONOMICS LEARNING OUTCOMES
}

\author{
Muhamad Iqbal Hutanto \\ Economics Education Department, Universitas Negeri Surabaya \\ Email : muhamadhutanto16080554037@mhs.unesa.ac.id
}

Website: http://jurnal.uin-antasari.ac.id/index.php/itjik

Received: 20 November 2020; Accepted: 3 June 2021; Published: 24 June 2021

\begin{abstract}
The research objective was to analyze the effect of discipline, learning facilities and peers on the economic learning outcomes of class XI students at SMAN 2 Probolinggo partially or simultaneously. This type of research uses a quantitative approach, a total sample of 97 students. Researchers used a questionnaire that was distributed to students. To ensure that the learning discipline influences, learning and peer facilities are really at the center of learning. The results of the study show that learning discipline, learning facilities and peers simultaneously have a positive effect and partially have a positive effect on learning outcomes. Through this research, it is able to explain student learning outcomes by $71.2 \%$. The rest is influenced by variables outside the study.
\end{abstract}

Keywords : discipline; learning facilities friend class; economic learning outcomes

\section{INTRODUCTION}

Education has an important role in improving the quality of human resources, given the increasingly fierce competition between countries in the era of globalization from trade, technology, resources to the arts. According to (Sardiman, 2001) "Education and teaching is one of the efforts that are conscious of the purpose of being systematically directed at changing behavior towards the maturity of students. Therefore, education is carried out individually and in harmony as stated (Anggraini, 2014) said that the educational process lasts a lifetime and in all contexts and circumstances that are not limited. This explains that the education received by a person lasts during his lifetime.

The education process is supported by good learning. The benchmark for success in a learning process that has been done previously can be measured by value. This value is usually in the form of student learning outcomes. Learning outcomes are the result of reciprocity between teachers and students in the teaching and learning process. This is in accordance with the opinion that has shown how much individual ability is put forward by (Anggraini, 2014), Learning outcomes in understanding the learning material that has been taught with the learning outcomes obtained, then an evaluation is carried out on the things that cause individuals to lack understanding and mastery of the subject matter being taught.

Based on preliminary research conducted by researchers at SMA Negeri 2 Probolinggo, which is located on Jalan Ki Hadjar Dewantara, 01, Kanigaran, Kanigaran District, Probolinggo City, information was obtained that the KKM criteria in economic subjects was 80. Based on information obtained from interviews between researchers and teachers economics subject named Octaviana, S. Pd. The results explained that some students were less responsive to the directions given by the teacher. In addition, he stated that another cause of the low student learning outcomes is because there are still some students who have difficulty learning independently and doing the assignments given by the teacher, this is evidenced by the delay in students collecting assignments. 
(Tu'u, 2004) Learning discipline is obedience to rules related to learning problems with self-awareness in order to follow the rules that have been applied in certain environments. According to him, a learning environment that applies discipline will produce outstanding students. Because students who excel are born from habits in obeying the rules that apply at school, so they can make success in learning. Based on an interview at SMA Negeri 2 Probolinggo. This school has been very good at implementing discipline in school rules. The rules at SMA Negeri 2 Probolinggo are obedience to time to come to school, time to study in class, collection of assignments that have been given by the teacher. As in research (Dina Ulfa, 2017) entitled "Influence of Motivation To Learn, Learn Discipline, Learning Style, and Facilities Study of Achievement Class" X SMK in Jakarta that the data in this study uses SPSS version 22 using reliability test, normality test, classical assumption test, multiple regression equation, hypothesis testing and the coefficient of determination. The results showed that the variables of learning motivation, learning styles and learning facilities had an influence on student achievement in class X SMK in Jakarta, and the three variables were jointly meaningful and had a significant correlation between learning motivation, learning discipline, learning discipline, learning style, as well as learning facilities about student achievement in class X SMK in Jakarta. However, it is not entirely done by students, not a few students who violate the discipline that has been given, especially in the ongoing economic learning process. There are 3 students who are often late for class when changing lessons, not being on time when collecting assignments, and often joking and chatting with their friends when the teacher explains. This happens because there are about 3 students who do not have an awareness of the importance of discipline. For example, during the lesson. In addition to learning discipline, there are also learning facilities capable of influencing learning outcomes.
This happens because there are about 3 students who do not have an awareness of the importance of discipline. For example, during the lesson. In addition to learning disciplines, there are also learning facilities capable of influencing learning outcomes. This happens because there are about 3 students who do not have an awareness of the importance of discipline. For example, during the lesson. In addition to learning disciplines, there are also learning facilities capable of influencing learning outcomes.

According to (Werdayanti, 2018) learning facilities are one of the efforts to realize learning objectives have a role in increasing student motivation. In a study entitled "The effect of achievement motivation, learning discipline and learning facilities on student learning outcomes", it is also stated that the results of the partial hypothesis test explain that the achievement motivation variable has a significant influence on learning outcomes, the learning facilities variable has a significant influence on learning outcomes, and simultaneously there are independent variables of achievement motivation, learning discipline and learning facilities have a significant effect on student learning outcomes, teachers help students in the form of support so that students obey the rules and schools provide facilities for student learning success. Furthermore, peers also affect student learning outcomes.

According to (Tirtarahardja, 2010) Peer indicators include peer support in learning, social interactions carried out by students with students, activities that students have received at school, as well as good learning partners. Education currently uses the 2013 curriculum, as well as schools that are used as research objects by researchers. So that the learning time owned by students is used more in school, rather than student interaction with family. So that the source of student information that has not been obtained through his family he can get from his peers. Based on the theory put forward by (J. W. Santrock, 2009), peers play a role in sharing information about 
unfamiliar things. Peers produce interaction relationships about the advantages that they each have and can choose between right and wrong. The influence of peers has not been able to provide learning to their friends. The laziness that his friend did was imitated and carried out by other friends. In addition, there are 3 students who come late to school, some do not wear full attributes. So it is not a little if there are assignments from teachers who are ignored or collected late. The responses given by the students did not give good results.

Based on research conducted by (Ryan Pyrba, 2018) states that there is a simultaneous or partial influence between the student learning process, the influence of learning discipline on student learning outcomes has a magnitude of $5.01 \%$, the family environment on student learning outcomes has a magnitude of $7.12 \%$ on student learning outcomes has a magnitude of $15.60 \%$.

From previous studies, negative results were obtained, the results obtained were not explained in detail, only limited to variables, but different from the results of this research, it is hoped that they will have a greater effect on improving learning outcomes.

Based on the background that has been described, the researchers are interested in conducting further research on "The Influence of Learning Discipline, Learning Facilities, and Peers on Economic Learning Outcomes of Class XI Social Studies Students at SMAN 2 Probolinggo.

\section{RESEARCH METHODS}

This study aims to determine the effect between the variables of Learning Discipline (X1), Learning Facilities (X2) and Peers (X3) on Learning Outcomes (Y). In this study, the researcher used a saturated sampling technique, where the entire population in the study was used, namely students of class XI IPS 2 at SMAN 2 Probolinggo, totaling 97 students. In this study, in the early stages of the study, observations were made to class XI students in order to find out how is the condition of economic learning in the material of national opinion carried out by students in the classroom. During class, some students often make noise in the classroom so that the learning process becomes hampered. Then the researchers distributed research questionnaires to students so that the research results came out of the influence of learning discipline variables, learning facilities and peers on student learning outcomes. The questionnaire contains 48 questions where each variable consists of 16 questions. The questionnaire was about learning discipline, learning facilities and peers.

The questionnaire distributed was a closed instrument containing the independent variables and the dependent variables studied. Respondents must choose the answer already available. The measurement scale in this study was using a Likert scale with five alternative answers, given a score of 1 to 5. The learning discipline variable consisted of 16 statement items, the facility variable consisted of 16 statement items and peers consisted of 16 statement items. All instruments used have been tested for validity and reliability. The data obtained is then transformed first and then tested for classical assumptions, including normality test, multicollinearity test, heteroscedasticity test, and linearity. The normality test of this study used the Kolmogrov - Smirov non-parametric statistical test.

This type of research uses a quantitative approach to measure the magnitude of the learning discipline variable on learning outcomes, learning facilities on learning outcomes, and peers on learning outcomes. Researchers will examine the partial relationship of learning discipline (X1), learning facilities (X2) and peers (X3) on learning outcomes and the good or bad learning outcomes obtained by students. The research design to be carried out is as follows. 


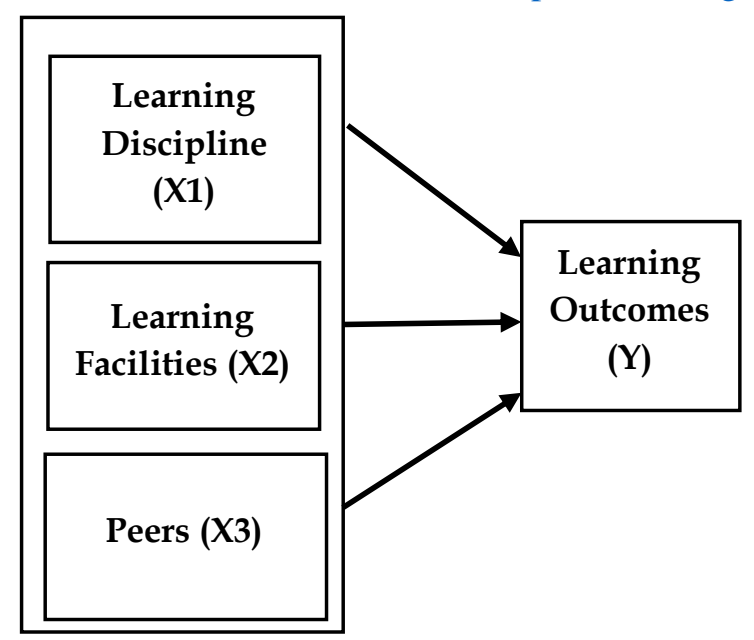

Picture 1. Research's Variables

The subjects of this study were students of class XI IPS SMAN 2 Probolinggo. While the research instruments used in this study were questionnaires and documentation. The following are data collection techniques Questionnaire

According to (Sugiyono, 2015) "Questionnaire is a data collection technique that is carried out by giving written questions to respondents to be answered". The questionnaire used in this study used a closed questionnaire and the scoring was based on the Likert scale. The researcher chose to use the armature due to collect data from the variables of learning discipline, learning facilities, and peers on learning outcomes. This questionnaire was given to respondents, namely all students of class XI IPS SMAN 1 Probolinggo, then respondents answered questions according to actual conditions.

Documentation

(Sugiyono, 2015) argues that documentation is a record of events that have passed, in the form of pictures, writings, or monumental works of someone. The purpose of the researcher using documentation is to look at the data on the names and daily economic test scores of all students of class XI IPS SMAN 2 Probolinggo on demand and supply.
The data analysis technique is data transformation to fulfill the influence test requirements, then the type of data used is interval or ratio. While the list of questions answered by respondents in the questionnaire produces ordinal data, therefore data transformation is needed. In addition to the classical assumption test, there are several ways, namely normality test, heterocodestity test, linearity test, multiple linear analysis, hypothesis testing.

Data was collected using observation and questionnaire techniques. The observation technique aims to determine the conditions directly in the field, while the questionnaire is used to obtain data from data sources or respondents. The questionnaire contains statements that have been validated and stated to be reliable for each indicator item.

Before carrying out the first statistical test, data transformation must be carried out from ordinal data to interval data. After the data is transformed, the classical assumption test, multiple linear regression and hypothesis testing are carried out. The analysis of the influence of the variables partially uses the T test, while the analysis of the influence of the variables simultaneously uses the F test (Ghozali, 2011) .

\section{RESULTS AND DISCUSSION}

Based on the normality test of the data, it is known that the asymp value. Sig (2-tailed) of $0.200>0.05$, thus it can be said to pass normality or the data is normally distributed.

Multicollinearity can be seen from the value of the variance inflation factor (VIF). The results of the multicollinearity test analysis show that the VIF value is 1.554 $<10$, it can be stated that there is no multicollinearity. Heteroscedasticity test using the glejser method. The results of the analysis obtained the value of sig. $0.174>$ 0.05 on the variable of learning discipline, $0.542>0.05$ on the variable of learning facilities and 0.118 on the peer variable, it can be concluded that there is no heteroscedasticity in the regression model 
used. The results of the linearity test are seen from the sig value. deviation from linearity the result is 0.000 The learning discipline variable is linearly related to the learning outcome variable, the learning facilities variable is linearly related to the learning outcomes variable and the peer variable is linearly related to the learning outcomes

Variable with a sig value. deviation from linearity of 0.000 The following are the results of the $\mathrm{T}$ and $\mathrm{F}$ tests.

Table 1. T Test Results

\begin{tabular}{|c|c|c|c|c|c|c|}
\hline \multicolumn{7}{|c|}{ Coefficients $^{\mathrm{a}}$} \\
\hline & \multirow[t]{2}{*}{ Model } & \multicolumn{2}{|c|}{$\begin{array}{l}\text { Unstandardized } \\
\text { Coefficients }\end{array}$} & \multirow{2}{*}{$\begin{array}{c}\text { Standard dized } \\
\text { Coeffici ents } \\
\text { Beta }\end{array}$} & \multirow[t]{2}{*}{$\mathrm{T}$} & \multirow[t]{2}{*}{ Sig. } \\
\hline & & B & Std.Error & & & \\
\hline \multirow{4}{*}{1} & (Constant) & 117,573 & 2.090 & & 56,252 &, 000 \\
\hline & $\begin{array}{l}\text { Discipline in } \\
\text { study }\end{array}$ &,- 498 & ,078 &,- 438 & 6.413 & ,000 \\
\hline & $\begin{array}{l}\text { Facilities } \\
\text { study }\end{array}$ &,- 423 & ,096 &,- 314 & 4.418 & ,000 \\
\hline & Peers &,- 366 & , 109 &,- 259 & 3.346 & .001 \\
\hline
\end{tabular}

Based on Table 1 above, the results of the $t$ test analysis can be obtained t table by means of $\mathrm{df}=\mathrm{nk}=97-4=93$, so that the t table with df 93 is 1.98580 From table 1 shows that the learning discipline variable has a significant effect on the learning outcome variable with a $t$ value count $=$ - $6.413<\mathrm{t}$ table $=1.98580$ or $\mathrm{p}$ value $=0.000$ then Ho is rejected. The learning facility variable has a significant effect on the learning outcome variable with $\mathrm{t}$ count $=$ $4.418<\mathrm{t}$ table $=1.98580$ or $\mathrm{p}$ value $=0.000$ then Ho is rejected.

Table 2. F Test Results

\begin{tabular}{|c|c|c|r|c|c|c|}
\hline \multicolumn{7}{|c|}{ ANOVA $^{\mathbf{a}}<0}$, \\
\hline \multirow{2}{*}{1} & Model & $\begin{array}{c}\text { Sum of } \\
\text { Squares }\end{array}$ & df & $\begin{array}{c}\text { Mean } \\
\text { Square }\end{array}$ & F & Sig. \\
\hline \multirow{3}{*}{1} & Regressin & 3139,866 & 3 & 1046,622 & 79.927 &, 000 \\
\cline { 2 - 8 } & Residual & 1217,804 & 93 & 13,095 & & \\
\cline { 2 - 8 } & Total & 4357,670 & 96 & & & \\
\hline
\end{tabular}

Based on the table above, peer variables have a significant influence on the learning outcomes variable with $\mathrm{t}$ count $=$ $3.346<\mathrm{t}$ table $=1.98580$ Then $\mathrm{Ho}$ is rejected.

The F statistic test shows the value of Fcount $=79.927>$ F table $=2.70$ Significant of $0.000<0.05$, so the regression model can be used which means that the variables of learning discipline, learning facilities and peers simultaneously have a significant effect on the dependent variable, namely learning outcomes.

$$
\begin{aligned}
& \text { Df1 }=\mathrm{k}-1 \\
& \text { Df2 }=\mathrm{n}-\mathrm{k}
\end{aligned}
$$

The results of the regression are: the learning discipline variable (X1) has a positive effect on the learning outcome variable (Y), the learning facilities variable (X2) has a positive effect on the learning outcome variable $(\mathrm{Y})$ the peer variable $(\mathrm{X} 3)$ has a positive effect on learning outcomes (Y) . The coefficient of determination test is known that the adjusted r-square value is $71.2 \%$ or 7.12 . It can be concluded that the ability of the independent variable to explain the dependent variable is $71.2 \%$ and the remaining $28.8 \%$ is explained by other variables that are not included. 
The Effect of Learning Discipline on Economic Learning Outcomes of Class XI Social Sciences at SMAN 2 Probolinggo.

Based on the descriptive analysis on the t-test, it shows that the learning discipline variable has a significant and positive effect on the economics learning outcomes of students in class XI IPS at SMAN 2 Probolinggo. Thing this shows that discipline study influential in improving student learning outcomes.

The results of the analysis that have been carried out can be seen that Learning Discipline (X1) has an effect on positive nor significant to student learning outcomes (Y). It can be seen in the table that the $t$ test results show a significance value of 0.000 where the value is 05. It shows that the influence of student learning discipline is not too large, but it still has a consistent effect. The point is that students' learning discipline is not good, so it mentions a decrease in student learning outcomes at school.

If students can apply the habit of learning discipline in school well, it will be easy to form concentration in student learning activities. In class XI IPS at SMAN 2 Probolinggo already have a fairly good learning discipline but it is necessary to increase self-awareness in obeying all the rules that exist at school and at home. As in terms of punctuality to come to school in accordance with the rules set by the school, wearing complete school attributes, especially on Mondays for the flag ceremony, and not making a noisy class atmosphere, especially during the learning process This is in line with (Saputro, Singgih Teguh, 2012) who argues that "in order for students to learn more advanced, students must be disciplined to study at school, at home and in the library". according to the opinion of (Resti, 2014) Students who are able to divide their time between playing and studying will appreciate the time they have more.

The results of the research above, can support previous research conducted by (Haries Pratama, Husni Syahruddin, 2012) with the title "The Influence of Student Learning Discipline on Learning Outcomes in Economics Subjects", which states that "there is a significant positive influence of learning discipline on economic learning outcomes for students of class XI Tourism SMK Panca Bhakti in taking Economics lessons".

\section{The Effect of Learning Facilities on Economic Learning Outcomes of Class XI Social Sciences at SMAN 2 Probolinggo}

Based on the descriptive analysis, the t-test showed that the learning facilities variable had a significant and positive effect on the students of class XI IPS SMAN 2 Probolinggo to get economic learning outcomes. This shows that learning facilities have an influence in improving student learning outcomes in schools. In accordance with the second hypothesis states that learning facilities have an effect on learning outcomes. In other words, if the existing learning facilities partially use the $\mathrm{T}$ test, while the analysis of the influence of variables simultaneously uses the test (Ghozali, 2011)

The results of the analysis that the researcher has done can be seen that the significance value in the $t$ test results table is 0.000 where the value is $<0.05$. Which means that partially the Learning Facilities variable (X2) has a significant effect on student learning outcomes at SMAN 2 Probolinggo. This shows that the learning facilities are supportive in the learning process. The more effective the existing learning facilities will have a positive impact on learning so as to be able to have an impact on increasing learning outcomes as well. Because learning facilities are very useful for the student learning process. This is in accordance with the opinion (Yuliani, 2014) with the title "The influence of learning facilities, classroom management, and family environment on economic learning outcomes through student motivation in class XI MA Al-Asror Semarang city. 


\section{The Influence of Peers on Economic Learning Outcomes of Class XI Social Sciences at SMAN 2 Probolinggo}

Based on the descriptive analysis, the t-test showed that the peer variable had a significant effect on the economics learning outcomes of class XI social studies students at SMAN 2 Probolinggo. This explains that peers make a positive contribution in improving student learning outcomes at school.

In the results of the analysis that the researchers did, it is known that the significance value in the $t$-test results table is 0.000 where the value $<0.05$ partially means that the peer variable (X3) affects the economic learning outcomes of SMAN 2 Probolinggo students. This shows that most students already have peers in helping the learning process. The more peers a student has to provide motivation in their learning and who behave positively, then it is able to have an impact on improving learning outcomes as well.

The results of the description of the data above are supported by the research that has been done (Saputro, Singgih Teguh, 2012) with the title "The Influence of Learning Discipline and Peer Environment on Student Achievement in the 2009 Accounting Education Study Program, Faculty of Economics, Yogyakarta State University". In the research he has done, it shows that the t-count value on the peer variable is greater than the significance level. This shows that peers have a positive influence on learning achievement under study.

\section{The Influence of Learning Discipline} Learning Facilities and Peers on Economic Learning Outcomes of Class XI Social Studies Students at SMAN 2 Probolinggo

Based on the results of the $F$ test analysis shows that learning discipline and peers have a positive and significant impact on improving students' economic learning outcomes, it can be seen from the value of the coefficient of determination. From these data, it is known that the contribution of learning discipline variables, learning facilities and peers is 71.2 to learning outcomes while the lack is influenced by other variables that are not studied. This shows that student learning outcomes can be obtained and influenced by other factors. For example, the attention of parents in a comfortable learning environment and motivation from within the student. The results of the analysis in this study indicate that student learning outcomes are influenced by learning discipline, meaning that if students have a high level of discipline in learning, then it will improve learning outcomes. Conversely, if the level of student discipline in learning is low, then student learning outcomes will be low.

Learning facilities also play a role in improving learning outcomes. If learning facilities are available and used properly, it will play an important role in learning success. Because in learning requires support during learning takes place. From some of the information collected, the school has learning facilities. The more effective the student learning facilities, the more successful learning will be achieved.

In addition to learning outcomes from student acquisitions in this study, peers are also influenced. The point is that if the group of peers owned by students is classified as a group that has high learning achievement, then this can also encourage students to personally balance their peers, which is to improve their learning outcomes.

In line with the results of research conducted by (Saputro, Singgih Teguh, 2012) entitled "The Effect of Discipline in Learning and Peer Environment on Student Achievement in Accounting Education Study Program Class of 2009 Faculty of Economics, State University of Yogyakarta", which shows that there is a positive and significant influence on learning discipline and peer variables on learning achievement. In addition, the same opinion has also been expressed by (Arista, 2018), with the title "The Influence of Study Discipline and Peers on Learning Outcomes 
in Economics Subjects for Class XI Social Sciences at SMA Negeri 1 Kedamean Gresik" which states that learning discipline and peers have a simultaneous effect on student learning outcomes. From some of the opinions above, it can be concluded that the higher the level of learning discipline obtained by students and the greater the positive influence of peers that a student has, then it is able to increase the acquisition of student learning outcomes that have been obtained.

\section{CONCLUSION}

Based on the results of the analysis, namely the data that has been carried out, information is obtained that learning discipline, learning facilities and peers affect learning outcomes partially or simultaneously. Seeing the research conducted that learning discipline, learning facilities and peers contributed $72 \%$, but it is necessary to investigate further about other variables that affect learning outcomes.

\section{REFERENCES}

Anggraini, E. (2014). Pengaruh Pergaulan Teman Sebaya dan Motivasi Belajar terhadap Hasil Belajar Ekonomi Siswa Kelas XI Ilmu Pengetahuan Sosial Sekolah Menengah Atas Negeri 1 Sukodono Tahun Ajaran 2013/2014.

Arista, I. D. (2018). Jurnal Pendidikan Ekonomi. Pengaruh Disiplin Belajar Dan Teman Sebaya Terhadap Hasil Belajar Pada Mata Pelajaran Ekonomi Siswa Kelas XI IPS Di SMA Negeri 1 Kedamean Gresik, 6, 302-309.

Dina Ulfa. (2017). Influence of Motivation To Learn, learn Discipline, Learning Style, and Facilities Study of Achievement Class X SMK In Jakarta.

Ghozali. (2011). Aplikasi Analisis Multivariate dengan Program IBM SPSS 20.

Haries Pratama, Husni Syahruddin, M. B. (2012). Pengaruh Disiplin Belajar Siswa Terhadap Hasil Belajar Pada
Mata Pelajaran Ekonomi.

J. W Santrock. (2009). Psikologi Pendidikan. Jakarta: Salemba Humanika.

Resti, M. (2014). Jurnal Disiplin Belajar. Pengaruh Kedisiplinan Siswa Dan Perhatian Orang Tua Terhadap Hasil Belajar Matematika Siswa Kelas 4 SD Se Kecamatan Ajibarang Tahun Ajaran 2013/2014.

Ryan Pyrba, A. R. (2018). No Title. Pengaruh Disiplin Belajar, Lingkungan Keluarga Dan Motivasi Belajar Terhadap Hasil Belajar Siswa Kelas X Administrasi Perkantoran Di SMK N 2 Temanggung, 341-342.

Saputro, Singgih Teguh, dkk. (2012). Pengaruh Disiplin Belajar dan Lingkungan Teman Sebaya terhadap Prestasi Belajar Mahasiswa Program Studi Pendidikan Akuntansi Angkatan 2009 Fakultas Ekonomi Universitas Negeri Yogyakarta. Jurnal Pendidikan Ekonomi, 10 (1), 78-79.

Sardiman. (2001). Interaksi dan Motivasi Belajar Mengajar. 2.

Sugiyono. (2015). Metode Penelitian \& Pengembangan Research and Development. Bandung: Alfabeta.

Tirtarahardja, U. dan L. S. (2010). Pengantar Pendidikan. Jakarta: Rineka Cipta bekerja sama dengan DEPDIKBUD.

Tu'u. (2004). Peran disiplin pada perilaku dan prestasi siswa. Jakarta, 22.

Werdayanti. (2018). The effect of achievement motivation, learning discipline and learning facilities on student learning oucomes.

Yuliani. (2014). No Title. Anggraeni, E. (2014). Pengaruh Pergaulan Teman Sebaya Dan Motivasi Belajar Terhadap Hasil Belajar Ekonomi Siswa Kelas XI Ilmu Pengetahuan Sosial Sekolah Menengah Atas Negeri 1 Sukodono Tahun Ajaran 2013/2014. Pendidikan, 5-6. Anggraini, E. (2014). 
